International Journal of Social Science And Human Research

ISSN(print): 2644-0679, ISSN(online): 2644-0695

Volume 05 Issue 01 January 2022

DOI: 10.47191/ijsshr/v5-i1-31, Impact factor-5.586

Page No: 226-232

\title{
The Effectiveness of the Pre-Employment Card Program as Unemployment Benefits due to the Covid-19 Pandemic in Indonesia
}

\author{
Tien Norma Habsari ${ }^{1}$, Zainal Abidin Sahabuddin ${ }^{2}$, Sri Sundari ${ }^{3}$ \\ ${ }^{1,2,3}$ Economics Defense Department, Indonesia Defense University
}

\begin{abstract}
This study aims to analyze the effectiveness of the pre-employment card program approved by the government in reducing unemployment due to the COVID-19 pandemic. The COVID-19 pandemic that occurred in Indonesia caused an increase in unemployment. This is due to a decrease in production, which has an impact on the company's operations and finances. The government is the most responsible in the unstable economic conditions of society. One of the programs issued is the preemployment card program. This study uses a qualitative approach with descriptive analysis methods through collecting data from several books, journals, printed or electronic documents, and other sources of data or information. The research is intended to analyze the data by using data reduction techniques. The results of this study require the government to review the policies of this Pre-Employment Card program. The government must focus on providing assistance to the community in the form of Direct Cash Assistance (BLT), social assistance, to subsidies, and providing stimulus to companies or entrepreneurs to at least reduce the unemployment rate which leads to an increase in the number of unemployed.
\end{abstract}

KEYWORDS: Pre-Employment Card, Effectiveness, Unemployment, Covid-19 Pandemic.

\section{INTRODUCTION}

Since Covid-19 has infected almost all countries in the world, this has an impact on fundamental sectors in the country, such as the economic sector. It is not surprising then that the Indonesian economy has become weak. This is because, after the implementation of social distancing and the government issued Government Regulation Number 21 of 2020 concerning Large-Scale Social Restrictions in the Context of Accelerating Handling of Corona Virus Disease 2019 (Covid-19), then followed by the issuance of technical regulations, in the form of Regulation of the Minister of Health Number 9 of 2020 concerning Guidelines for Large-Scale Social Restrictions in the Context of Accelerating the Handling of Corona Virus Disease 2019 (Covid-19). Where several articles in the regulation regulate what jobs are allowed and not allowed to operate in the midst of a pandemic, even if they are allowed, then only a few sectors can Work From Home (WFH).

This certainly has an impact on the formal and informal sectors of employment. Many lower-middle-class companies have started to go bankrupt, not only the lower-middle-class companies that have been affected, but also large companies, such as the Ice Cream Aice company, have laid off hundreds of workers. Even though there are indications of violations there, of course we cannot ignore the impact of COVID-19, which has weakened the Indonesian economy.

In situations and conditions like this, of course, government policies are very important, because the policies issued by the government will determine the fate of the Indonesian people in the future. Therefore, to reduce the economic impact and maintain people's purchasing power, the government in this condition has accelerated the issuance of one of its magic cards, this card is called the Pre-Employment Card. This card is one of the social safety nets created by the government, which aims to develop competencies and opportunities for job seekers. Workers/laborers who are affected by the termination of employment, and/or workers/laborers who are in need of financial support.

\section{LITERATURE REVIEW}

\section{A. Effectiveness Concept}

\section{Definition of Effectiveness}

Effective is successful or something that is done successfully. Popular scientific dictionaries define effectiveness as the proper use, use or support of goals. Effectiveness is the main element to achieve the goals or targets that have been determined in each organization, activity or program. It is said to be effective if the goals or objectives are achieved as determined. 


\section{The Effectiveness of the Pre-Employment Card Program as Unemployment Benefits due to the Covid-19 Pandemic in Indonesia}

Efforts to evaluate the course of an organization, can be done through the concept of effectiveness. This concept is one of the factors to determine whether it is necessary to make significant changes to the form and management of the organization or not. In this case, effectiveness is the achievement of organizational goals through the efficient use of available resources, in terms of inputs, processes, and outputs. In this case, what is meant by resources includes the availability of personnel, facilities and infrastructure as well as the methods and models used. An activity is said to be efficient if it is carried out correctly and in accordance with procedures, while it is said to be effective if the activity is carried out correctly and provides useful results. So an organizational activity is said to be effective if an organizational activity runs according to the rules or runs according to the targets set by the organization.

2. Effectiveness Measure

Measuring the effectiveness of an activity program is not a very simple matter, because effectiveness can be studied from various perspectives and depends on who assesses and interprets it. When viewed from the point of view of productivity, a production manager provides an understanding that effectiveness means the quality and quantity (output) of goods and services. The level of effectiveness can also be measured by comparing the plans that have been determined with the actual results that have been realized. However, if the effort or the results of the work and actions taken are not appropriate, so that the goals are not achieved or the expected goals, then it is said to be ineffective.

The criteria or measures regarding the achievement of objectives are effective or not, namely:

a. Clarity of goals to be achieved, this is intended so that employees in carrying out their duties achieve targeted goals and organizational goals can be achieved.

b. The clarity of the strategy for achieving goals, it is known that the strategy is "on the road" which is followed in making various efforts to achieve the goals specified so that implementers do not get lost in achieving organizational goals.

c. The process of analysis and formulation of a solid policy, related to the objectives to be achieved and the strategy that has been set, means that the policy must be able to bridge the objectives with the efforts to implement operational activities.

d. Careful planning, essentially means deciding now what the organization will do in the future.

e. The preparation of the right program, a good plan, still needs to be spelled out in proper implementation programs because if not, the implementers will lack guidelines for acting and working.

f. Availability of work facilities and infrastructure, one indicator of organizational effectiveness is the ability to work productively. With the facilities and infrastructure available and may be provided by the organization.

g. Effective and efficient implementation, however good a program is if it is not implemented effectively and efficiently, the organization will not achieve its goals, because the implementation of the organization is getting closer to its goals.

h. An educational system of supervision and control considering human nature is not perfect, the effectiveness of the organization requires a system of supervision and control.

The criteria for measuring effectiveness, namely: Productivity, Ability to adapt to work, Job satisfaction, Profitability, Search for resources. Meanwhile, Richard M. Steers said about the effectiveness measure, as follows:

a) Achieving Goals is the overall effort to achieve goals must be viewed as a process. Therefore, so that the achievement of the final goal is more secure, phasing is needed, both in the sense of phasing in the achievement of its parts and phasing in the sense of its periodization. The achievement of goals consists of several actors, namely: Time period and targets which are concrete targets.

b) Integration is a measurement of the level of ability of an organization to conduct socialization, consensus development and communication with various other organizations. Integration concerns the socialization process.

c) Adaptation is the organization's ability to adapt to its environment. For this reason, a benchmark for the procurement and filling process is used.

\section{METHODOLOGY}

In this study, researchers used a qualitative approach with descriptive analysis methods through data collection which was described in detail and regularly. Data collection techniques through documentation are carried out through reviewing and/or browsing several books, journals, printed or electronic documents, and other sources of data or information deemed relevant to the research or study (Supriyadi, 2017). The research is intended to analyze the data by using data reduction techniques.

\section{RESULT AND DISCUSSION}

Pre-employment Card Program by involving multi-company partnerships. The Pre-Employment Card program has become very meaningful to help small communities in meeting their living needs and maintaining food welfare for a certain period of time. The impact of COVID-19 can be said to have been slightly overcome through the Pre-Employment Card program, however, not all people are able to get access to the Pre-Employment Card program due to many prevailing factors such as the tight selection process, 


\section{The Effectiveness of the Pre-Employment Card Program as Unemployment Benefits due to the Covid-19 Pandemic in Indonesia}

limited information, willingness, interest, and so on. The Pre-Employment Card emerged as a program that provides open space and the potential to trigger the development of creativity for small communities through an online training system.

In the Pre-Employment Card program, the public is also provided with broad access to improve their competence in certain fields. In addition, various digital platforms also accompany pre-employment processes and services such as Tokopedia, Bukalapak, Skill Academy, Ministry of Manpower, Pintaria, Pijar, Sekolah.mu, and MauBelajarApa (Wijayanti \& Humardhiana, 2020).

The Pre-Employment Card Program is very relevant to the theory from Olaniyi (2020) which states that when the economic condition of the community declines drastically, the government is the party who is fully responsible for taking strategic steps to overcome economic difficulties that plague the community. The economic condition of the community is the main reference that is the burden and responsibility of the government as the authority, especially when there is an emergency or obstacles occur at any time (Kurniawansyah, et al 2020).

Due to the widespread increase in the number of victims of COVID-19, the Indonesian government is looking for solutions to deal with the problems that occur. This is the impact of the declining business climate that occurs in Indonesian society, starting from the decline in productivity levels, business closures, and layoffs. In this case, the Indonesian government is the subject who is responsible for threats to the national economy. Through the issuance of Government Regulation in Lieu of Law (Perppu) No. 01 of 2020, one of the programs being promoted is the Pre-Employment Card with a target of 5.6 million people (specifically) affected by the COVID-19 pandemic. In the Pre-Employment Card program, the community has two rights, namely 900 types of online training as access to improve their own capabilities (according to their respective talents and interests), as well as financial assistance for other purposes (Pratiwi, 2020).

In terms of the registration mechanism, the Indonesian government does not discriminate between individuals. All have the same opportunity, as long as they are Indonesian citizens, aged 18 years and not being, are welcome to register online. Furthermore, if the registrants have passed the file selection, then the next step is to take the motivation and basic ability test. For participants who pass, they are allowed to take part in the training and will get an electronic certificate when the training is over. In addition, the nature of the disbursement of the coaching money is with a note that participants must first take part in a form of training which is expected to be used for further development and personal capital after the training (Pratiwi, 2020).

Government action is something that is understood about the steps in setting policy. However, if the policy is related to its relevance to the situation and conditions in a country including Indonesia, then the public or society will be directly affected. So that the manifestation of the quality of policies implemented by the government, of course, is a determining factor for the situation. An example is in the case of Pre-Employment Cards, where the government includes digital touch and intermediaries to empower communities through various strategic trainings. In this case, it can be seen how the government's efforts to equip citizens to become skilled and agile, in order to further support their daily ability to survive.

The presence of the Pre-Employment Card program is a strategic step from the Indonesian government which is certainly motivated by high concern for the community. Especially during the current COVID-19 pandemic, where the majority of people are at a stalemate, especially regarding the fulfillment of (economic) needs. All activities become hampered, or indeed decrease in productivity and income. This is supported by data on tax revenues which are under pressure due to weakening industrial trends as well as international trade and economic activity. At the end of March 2020 both the government and business sectors experienced a business slowdown in line with the regulations related to WFH (Work From Home). In total, Indonesia experienced a decrease in tax revenues in the first quarter of 2020 which was recorded to be minus $2.5 \%$, and automatically affected the 2020 State Budget figures. Some tax instruments that were minus after being used for handling Covid-19 were Corporate Income Tax and Taxes in Import order (PDRI) consists of several types, namely Income Tax (PPh) article 22 imports, PPh article 22 exports, Import Value Added Tax (VAT), and Sales Tax on Luxury Goods (Silalahi \& Ginting, 2020).

So that in the end, these various reasons also underlie the government in formulating ideas, and make the Indonesian government to be active in reading the weaknesses that exist in small communities. However, the realization of the Pre-Employment Card program has so far been realized in the field. Then, one of the targets expected by the implementation of the Pre-Employment Card program are such as: people affected by COVID-19, Micro small and Medium Enterprises, and people affected by layoffs.

In general, there are two large groups of participants based on the results of the combined analysis between the concepts of correctness of training targets and accuracy of social assistance targets. The first group is participants who fit the target, both for training and social assistance. The second group is participants who are not in accordance with the training objectives, but are very in line with the social assistance goals. A small proportion are participants who are in accordance with the training objectives, but are not in accordance with the social assistance goals.

\section{Participants in Accordance with the Target of Training and Social Assistance}

Participants belonging to this group generally choose training based on their career plans to increase competence and productivity in their current job field. For example, an online motorcycle taxi driver in Bali took English language training so he 


\section{The Effectiveness of the Pre-Employment Card Program as Unemployment Benefits due to the Covid-19 Pandemic in Indonesia}

could communicate with foreign tourists. In addition, there are some trainees who want to acquire new knowledge so that the opportunity to switch professions can be opened. Work experience also influences some participants in choosing the type of training.

Participants in this group are also highly motivated and willing to exchange the social assistance they receive for training activities. They recognize the need to improve competence and learn new skills/knowledge to get a better job.

Most of the pre-employment card program participants who were in line with the training targets also experienced a decline in economic activity due to the pandemic. For example, one respondent who worked as an extra on a television program experienced a significant decrease in income due to the COVID-19 pandemic after the large-scale social restriction (PSBB) policy was implemented. In general, they consider that the social assistance component of the pre-employment card program lightens their expenses.

\section{Participants who do not Match the Training Objectives, but are very in Line with the Social Assistance Goals}

Participants in this group lack the aspirations to pursue a career. One respondent admitted that he did not have any career goals or plans. Some of the other participants admitted that they wanted to have a better job, but did not make serious efforts to make their wish come true. The type of training that is often chosen is the training recommended by a friend or one that is easy to follow and quick to complete.

Participants who are not in accordance with the training objectives, but are very suitable for the objectives of the social assistance program Participants in this group lack the aspirations to pursue a career. One respondent admitted that he did not have any career goals or plans. Some of the other participants admitted that they wanted to have a better job, but did not make serious efforts to make their wish come true. The type of training that is often chosen is the training recommended by a friend or one that is easy to follow and quick to complete.

To overcome these problems, they usually rely on relatives or parents to get loans while looking for other sources of additional income. In fact, there are also respondents who have to sell their assets to meet their daily needs. The low level of economic resilience can be seen from the utilization of all social assistance to meet daily needs and pay debts. Because their financial capacity is very limited, they are generally very careful in using internet quota for things that are not related to work, including training.

According to data from the Ministry of Social Affairs, some of the impacts felt by the community are not small, namely in the economic, social, educational, and health fields. However, the biggest impact can be seen from how limited various community activities outside the home are, due to heeding the government's appeal (PSBB) to refrain from leaving the house as much as possible unless it is really urgent. In the end, this also has an impact on the socio-economic conditions of many small communities with various livelihood backgrounds, because the context is that they must maintain their survival for a while in the midst of impartial conditions (Pratama, 2020).

Some data on social, economic, educational, and health problems have actually appeared in various news. Like the following examples. Namely:

a. Economic Problems, quoted from (Anjaeni, 2020) that the Minister of Finance Sri Mulyani revealed that there were at least 3 economic cases in the country, such as:

1) In the SMES and informal sectors due to restrictions on interaction and physical contact, economic activity declines.

2) Weakened investment due to uncertainty, both for those who will invest and those who are currently investing.

3) The export sector was hit, because the whole world experienced a weakening. This is reflected in the decline in commodity prices from oil, coal, to Crude Palm Oil (CPO).

b. Social Problems, quoted from (Puspensos, 2020) explained that there was social dysfunction at the community level due to COVID-19. An example of a symptom of social dysfunction is the attitude of people who become more susceptible to suspicion, because they think that other people carry COVID-19 in their bodies. Like the people in Sawangan Depok, who refused to bury the bodies who died as a result of COVID-19. They assume that COVID-19 will continue to spread, even after the bodies have been buried. Whereas medically, bodies that have been processed at the hospital will certainly not cause the virus to spread again.

c. Education Problems, quoted from (Sumardiyani, 2020) The Mayor of Bogor (Bima Arya) told the Minister of Education and Culture (Nadiem Makarim) in July 2020 that access to quotas and internet, problems with online learning curriculum, and payment schemes for tuition fees are the main problem.

In addition, the Indonesian government's social awareness can actually be measured from the realization of the PreEmployment Card program. In fact, you could even say, with the existence of this program, the community has the potential to improve their self-quality and the nature of their excessive dependence on others. Therefore, based on the explanation above, it would be very interesting to examine how the government's concern for the community has been in responding to the COVID-19 pandemic to this day. Because on the other hand, both empowerment and welfare are fundamental agendas that should be the responsibility of the government in Indonesia. However, in this research, the main focus is on how the government comes up with 


\section{The Effectiveness of the Pre-Employment Card Program as Unemployment Benefits due to the Covid-19 Pandemic in Indonesia}

ideas and solutions that are also supported by many digital platforms, giving rise to a new breakthrough in the form of the PreEmployment Card program. The level of effectiveness of the Pre-Employment Card program in the end also has relevance to the discourse on community empowerment, and the rest depends on the way the government manages the program. In addition, related to access that is too free for the community without being accompanied by attention to economic background, it also raises new problems.

Although in principle the government has committed to launching the Pre-Employment Card program for people affected by the COVID-19 pandemic, the government is still unable to fully control the enthusiasm of the people who register. It's very possible if some of the registrants are in fairly good condition, or in another sense are well off. If examined, this is an inequality where groups of people who really need it will be automatically eliminated (due to the selection process). When compared between the government's principles and the practice of absorbing Pre-Employment Card participants in the field, the correlation is very ambiguous, but in the end this possibility can lead to a new hypothesis that needs special attention.

Through Presidential Regulation Number 36 of 2020 concerning the Development of Work Competencies through the PreEmployment Card Program, then followed by the issuance of technical regulations, namely, Minister of Finance Regulation (PMK) Number 25/PMK.O5/2020 concerning Procedures for Allocation, Budgeting, Disbursement, and Accountability of the PreEmployment Card Fund, this card was officially launched.

Actually, this Pre-Employment Card is one of the realizations of President Jokowi's campaign promise to create premium human resources capable of competing at home and abroad with a focus on training individual skills and preparing the workforce to be able to compete in the world of work.

You could say that the Pre-Employment Card program did not run smoothly, because before its launch it was also a polemic in the community. Starting from the accelerated release schedule, the initial budget of 10 trillion to 20 trillion, to the alleged conflict of interest that befell several special staff of the President. However, what is the main point of discussion this time is not the various polemics but, is this Pre-Employment Card effective as a social safety net for the people of Indonesia in the midst of the Covid-19 pandemic?

\section{Pre-Employment Card Effectiveness}

Pre-Employment, in which there are two words, namely; pra which means before and work which is "an activity to do something." If it is connected with the context of the discussion this time, it can be interpreted as "activities to earn a living." If it is related to the initial purpose of issuing this Pre-Employment Card, it is to prepare workers who do not have a job by providing a treatment, namely, improving soft skills in accordance with what is desired by Pre-Employment members with a forum prepared the government, both direct training to courses and online online training, in this case the government is collaborating with several online platforms such as Ruang Guru, Tokopedia, etc. However, this initial goal changed when Covid-19 hit Indonesia, people who were laid off were also covered by this card.

If viewed from the perspective of the Constitution, the Pre-Employment Card program is a form of implementation of Article 27 Paragraph (2) of the 1945 Constitution of the Republic of Indonesia which reads: "Every citizen has the right to work and a decent living for humanity." If you look closely, there are two core phrases in the article, namely; have the right to work and a decent living. This form of Pre-employment Card itself is only limited to providing a decent living. Then for the job? Here, the government does not guarantee whether after participating in the series of activities contained in the Pre-Employment Card program, you will get a job or not. This includes guarantees given to workers/labourers who have been laid off by company owners, whether they will get their jobs back after the Covid-19 storm ends. Even though this program must be accompanied by the availability of jobs that are comparable to the workforce so that this workforce can be absorbed.

According to data from the Central Statistics Agency (BPS), the total open unemployment rate as of February 2018 was $5.13 \%$, a number that is still fairly large for one of the indexes that is the benchmark for a country that is still mired in welfare or even poverty. Unemployment itself almost always intersects with poverty. BPS as an institution that is trusted to issue data related to poverty indicators states that a person is said to be poor if he is unable to meet his basic needs (basic needs approach).

Interestingly, poverty in Indonesia is included in the type of structural poverty. Structural poverty itself is more towards people or groups of people who remain poor or become poor because of the unequal structure of society, which is not beneficial for the weak (Dewanta, 1999). This can be caused by several factors, including the inability of the government to provide equal opportunities for the community in terms of preparing jobs, and because of the government's inaccuracy in deciding a policy.

Why is Indonesia not leaning towards cultural poverty? Because Indonesian people have started to open up to the outside world. Their thinking now is no longer limited to just eating today, but has started thinking about the future. This is evidenced by the existence of people who are urbanizing (Khairuddin, 2000). For example, Jakarta has always been a favorite destination for immigrants from villages who want to try their luck in the capital. Based on data from the DKI Population and Civil Registration Office (Dukcapil), as of 2017, there were 71,415 new arrivals to Jakarta. 


\section{The Effectiveness of the Pre-Employment Card Program as Unemployment Benefits due to the Covid-19 Pandemic in Indonesia}

If you look at current conditions, it is not appropriate to issue a Pre-Employment Card as one of the social safety nets provided by the government in the midst of the Covid-19 outbreak, because what the community needs now is quick and concrete assistance. Quick here is meant with assistance received directly without having to deal with procedurals or selection processes that can hinder the time for the aid to be dropped. The concrete here is that the benefits can be felt directly. This Pre-Employment Card itself can be said to be a form of the government's inability to provide employment, so the government only provides a hook and bait (PreEmployment Card) to look for fish (jobs) in lakes where there are few fish (jobs) and compete with others anglers (labor force).

A lot of the workforce is dominated by fresh graduates who still haven't got a job. Based on BPS data, as of August 2019, the number of unemployed university graduates reached 5.67 percent and the TPT for Vocational High Schools (SMK) was the highest among other education levels at 8.92 percent of the total workforce of around 13 million people. Not to mention the addition of all workers or laborers who have been laid off due to the impact of Covid-19.

Then what became more of a bomb was when the unemployed did not get a Pre-Employment Card. This of course will create social jealousy and cause waves of protests and even actions in various places. Not to mention that currently almost all work is done at home, even registration for Pre-Employment Cards must be online so that training for Pre-Employment Card participants is available online. Of course this is an obstacle because not all the quality of the Internet network in every area is the same.

\section{CONCLUSIONS}

Based on the exposition text above, it is necessary for the government to review the policies of this Pre-Employment Card program. It is important to improve soft skills, but if there are not enough job opportunities, the job opportunities will be smaller. More precisely, if the government now focuses on providing assistance to the community in the form of Direct Cash Assistance (BLT), social assistance, to subsidies, even if needed the government can provide a stimulus to companies or entrepreneurs to at least reduce the number of layoffs that lead to an increase in the number of unemployed. It should be remembered that the assistance must be in its entirety, not only partially in accordance with the mandate of the 5th Precept of Pancasila, that social justice is for all Indonesian people. The government and society must unite and collaborate in dealing with Covid-19, in accordance with the mandate of the 3rd Precept of Pancasila, namely Indonesian Unity.

\section{REFERENCES}

1) Anjaeni, R. (2020). Sri Mulyani revealed three economic problems caused by the Covid-19 pandemic. https://national.kontan.co.id/news/sri-mulyaniunjuk-three-problems-economy-yang-dikarenakan-pandemi-covid19?page $=2$

2) Bachtiar, et al. (2020). Pre-Employment Card in the Midst of the Covid019 Pandemic: Quick Assessment from the Viewpoint of Program Participants. Smeru Research Notes. No.3/2020.

3) Central Bureau of Statistics. 2019. August 2019: Open Unemployment Rate (TPT) of 5.28 Percent. https://www.bps.go.id/pressrelease/2019/11/05/1565/agustus-2019--levels of unemployment-open--tpt--sebesar-5-28persen.html, accessed Tuesday, (28 April 2020, 15:58 WIB).

4) Dewanta, Cloud Setya. (1999). Poverty and Inequality in Indonesia. Yogyakarta: Aditya Media.

5) Khairuddin, H. (2000). Community Development: Overview of Sociological, Economic and Planning Aspects. Yogyakarta: Liberty.

6) Kurniawansyah, Amrullah, M. S. (2020). Strategic Policy Concepts in Dealing with Economic Externalities From COVID -19 in Vulnerable Communities in Indonesia. Indonesian Journal of Social Sciences and Humanities, 1(2), 130-139. https://journal.publicationcenter.com/index.php/ijssh/article/view/117/57

7) Maggalatung, USA; Aji, A.M.; Yunus, N.R. How The Law Works, Jakarta: Jurisprudence Institute, 2014.

8) Novita, Imas; Saef, Muhammad; Khovshov, Alliza; Judge, Widiya. "Reformulation of the Foreign Worker Supervisory Agency System as a Form of State Defense in Indonesia," Staatrecht: Indonesian Constitutional Law Journal, Vol. 2, No. 1 (2017)

9) Pre-employment. (2020). Who is the Pre-Employment Card Program for?

10) Primary, F. (2020). Responding to the "New Normal" After the Pandemic. http://puspensos.kemsos.go.id/menyikapi-newnormal-after-pandemic

11) Pratiwi, N. (2020). The Effectiveness of Pre-Employment Cards in the Midst of the Covid-19 Pandemic https://kaltim.tribunnews.com/2020/04/28/effectiveness-kartu-prakerja-ditengah-pandemi-covid-19?page=2

12) Rahayu, Isna Rifka Sri. 2019. August 2019, Unemployment of University Graduates 737,000 People. https://www.inews.id/amp/finance/makro/per-agustus-2019-penangguran-lulusan-universitas-reach-737000-orang, accessed on Wednesday, (29 April 2020, 9:00 WIB)

13) Richard M. Steers. Organizational Effectiveness. Yogyakarta: Student Library, 1999. p.53. 
The Effectiveness of the Pre-Employment Card Program as Unemployment Benefits due to the Covid-19 Pandemic in Indonesia

14) Silalahi, D. E., \& Ginting, R. R. (2020). The Indonesian Government's Fiscal Policy Strategy to Regulate State Revenue and Expenditures in Facing the Covid-19 Pandemic. Jesya (Journal of Islamic Economics \& Economics), 3(2), 156-167. https://doi.org/10.36778/jesya.v3i2.193

15) Wijayanti, R. I., \& Humardhiana, A. (2020). Optimizing the Pre-Employment Card Program with Branding Strategy Training. TRUE, 2(1), 109-122. 